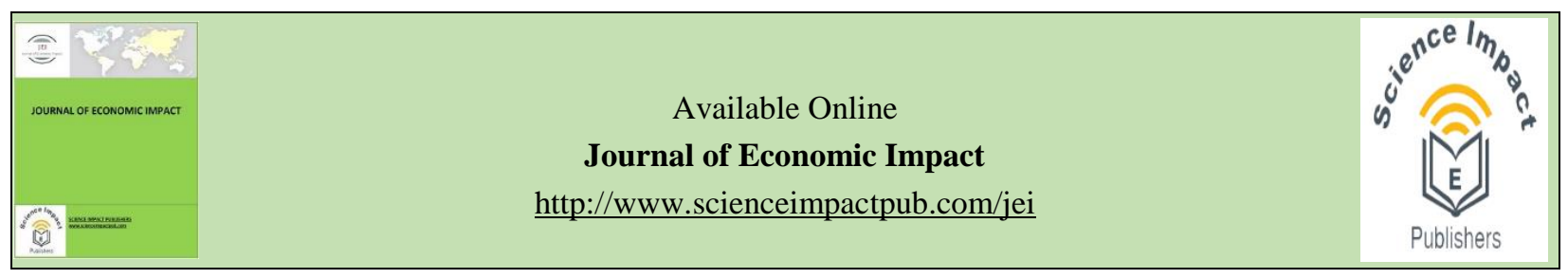

\title{
ON THE WHEAT PRICE SUPPORT POLICY IN PAKISTAN
}

\author{
Muhammad Aamir Shahzad a, Amar Razzaq a,*, Ping Qing b \\ ${ }^{a}$ College of Economics and Management, Huazhong Agricultural University, No. 1, Shizishan Street, Hongshan District, Wuhan, \\ Hubei Province 430070, PR China \\ ${ }^{b}$ Department of Marketing, College of Economics and Management, Huazhong Agricultural University, Hongshan District, Wuhan, \\ Hubei Province, China
}

\section{HIGHLIGHTS}

- The current wheat support price policy incurs a substantial economic burden on government exchequer.

- Pakistan's wheat production costs are higher than in neighboring countries.

- The results suggest that controlling and reducing input costs will benefit farmers and consumers.

- Providing input subsidies rather than purchasing subsidies will benefit producers and consumers and increase the international competitiveness of Pakistani wheat.

\begin{abstract}
Wheat is Pakistan's main food and strategic crop. Currently, the government controls wheat prices through a minimum support price (MSP) policy to encourage production. However, despite the increase in wheat production, input costs and output prices have been increasing over the years. This paper aims to analyse the impact of wheat support price policies. We use data from different government sources to estimate the financial implications of MSP and compare the support price policies of India and Pakistan. We find that Pakistan's current minimum support price policy encourages farmers to produce larger quantities of wheat, but this places a heavy financial burden on the country's finances. Our results indicate that the higher MSP of wheat has made the country lose its competitiveness in the international market. Besides, we found that the cost of wheat production in Pakistan is much higher than in India. These higher production costs force the government to raise the MSP to maintain farmers' profitability. The high MSP is guaranteed by subsidizing the procurement and release of wheat, which imposes a heavy financial burden on government finances. In addition, the rise in wheat prices in recent years has also hurt consumers. Policymakers can redistribute subsidies by subsidizing wheat inputs, especially fertilizers and seeds, to reduce production costs. To this end, the best policy intervention may be to provide input subsidies rather than subsidies on purchase prices. A reduction in input costs will correspondingly reduce output prices, which will increase farmers' profitability, consumer surplus and the international competitiveness of Pakistani wheat.
\end{abstract}

Keywords: Competitiveness; minimum support price; wheat procurement; Punjab; Pakistan; India.

Received: April 17, 2019; Accepted: May 21, 2019; Published: Oct 19, 2019.

* Correspondence: College of Economics and Management, Huazhong Agricultural University, No. 1, Shizishan Street, Hongshan District, Wuhan, Hubei Province 430070, PR China

Email: amar.razzaq@webmail.hzau.edu.com

\section{Introduction}

Wheat is the main strategic commodity in Pakistan. It is grown over 17.25 million acres (76\%) in Punjab province that accounts for $77 \%$ of the total production (19.28 million tons) $)^{1}$. Around $80 \%$ of farmers (45\% of the total population) depend on this crop for their livelihoods. In addition, wheat is essential for Pakistan's food security (Khan, 2014). The wheat price support policy (amended from time to time by the Cabinet's Economic Coordination Committee) aims to increase wheat productivity, support farmers' incomes, and provide food security through various subsidies and price controls. Policy interventions by the Pakistani government to maintain wheat production include input and output price regulations aimed at stimulating consumers and producers through multiple subsidies and tax plans. The Punjab government and the federal government have for many years involved in setting support price and procurement of wheat, with the main goal of protecting farmers from price shocks and ensuring a

${ }^{1}$ Data accessed at agriculture marketing information system website www.amis.pk on [16-03-2017]. 
stable supply to consumers at controlled prices. This intervention policy helps protect farmers and consumers from monopolists (intermediaries, price makers). Maintaining national reserves and ensuring food security at the low and subsidized prices are a major concern for the government (Khan et al., 2003). However, support prices and wheat procurement policies have put financial pressure on the Punjab government. The purchase of wheat at prices well above international prices and the inability to sell the product on the international market at the right price at the right time increase the country's economic burden. This study aims to analyze the shortcomings of current policies and propose future action plans.

Wheat is procured through the Pakistan Agricultural Storage and Services Corporation (PASSCO) at Federal level, and through Punjab Food Department at provincial level. For the year 2018-19, the Economic Coordination Committee (ECC) has decided to maintain the support price for wheat at the previous year's level of Rs.1300/40kg. Generally, there is a lack of literature on wheat support price policy analysis in Pakistan. However, few studies have attempted to highlight the nexus between support price and production of major crops in Pakistan. For instance, Ali (1990) argues that the support price of one crop affects the composition of other crops and therefore requires a careful analysis that considers the cross effects while changing the prices. The findings of Krishna (1963) indicate that farmers' decision to grow barley or wheat is affected by price rather than yield of crops in irrigated areas. For farmers, output prices are more important than any other factor. Niamatullah et al. (2010) show that raising support prices can protect farmers, traders and market participants, and increase the yield of specific crops while affecting nutrient intake and the acreage of other crops. However, the literature is silent on suggesting the optimal choice based on careful investigation of economic and financial impacts of intervention in wheat pricing policies.

The current procurement policy imposes a huge burden on the finances of the Punjab government through the high costs of procurement, processing, distribution and management of wheat stocks. Usually, the existing storage capacity is occupied by previous inventory and is not enough to store future what stocks. In addition, domestic wheat prices are higher than international prices, limiting the county's integration in the global market. The purpose of this paper is to discuss these issues in detail and propose policy options to achieve international competitiveness while protecting farmers and consumers.

\section{Financial Consequences of Wheat Stocks and Storage in Punjab}

According to FAO, the existing wheat system in Punjab is facing problems with storage facilities (Prikhodko and Zrilyi, 2013). There is a chronic shortage of storage facilities for wheat. Statistics show that the godowns store about $70 \%$ of the wheat, binishels store $13 \%$, hexagonal bins $7 \%$, bunkers $6 \%$, concrete silos $4 \%$, and the rest of the stock is covered with polyethylene. This heavy government intervention in the wheat market has limited private sector-driven development (FAO, 2013). However, recently, the government has been encouraging the private sector to enter the wheat market. The Asian Development Bank (ADB) is assisting the government to loosen controls on the wheat market. It provides loans to the government to restructure the functions of the food sector. According to ADB, targeted wheat subsidies and public strategic reserves are an effective policy mix to reduce food insecurity in Pakistan.

\section{Financial Repercussions of Wheat Procurement}

The financial consequences of large-scale procurement of wheat are severe enough to expose the government to the financial burden seen in recent years. For example, in 2016-2017 the government purchased 3.92 million tons of wheat at a minimum support price (MSP) of rupee. $1300 / 40 \mathrm{~kg}(32.50 / \mathrm{kg})$. This wheat stock was purchased by providing a subsidy of 9.51 rupee. per kilogram, resulting in a total loss of rupee. 37.36 billion. The amount of the loss depends on the difference between the purchase price and the release price and the quantity of wheat procured. The total cost of procurement is obtained by multiplying the total purchase quantity by the total purchase cost. The total cost of procurement in 201617 was 164.68 billion rupees while the expected return on stock sales was Rs. 127.4 billion (obtained by the release price multiplied by the quantity purchased). Table 1 shows the government's annual financial losses since 2011-12, reflecting the increase in losses during this period.

\section{Financial Repercussions of Bank Borrowings}

The procurement, processing, storage, maintenance and distribution of wheat stocks are financed through bank loans. The Punjab Food Department borrows from commercial banks every year, with interest rates between 9-12\% (World Bank, 2017). 
The government's wheat subsidy costs exceed Rs $5,500 /$ ton. Only last year, the government lost the rupee. 37.36 billion in wheat subsidies. Debt servicing of heavy loans constitutes a major component of the total payables.

Table 1: Financial Loss Due to Strategic Reserves in Punjab (Pakistani Rupees)

\begin{tabular}{ccccccccccc}
\hline Year & $\begin{array}{c}\text { Procureme } \\
\text { nt Punjab } \\
\text { (million } \\
\text { tons) }\end{array}$ & $\begin{array}{c}\text { MSP } \\
\text { (Rs/40K }\end{array}$ & $\begin{array}{c}\text { MSP/K } \\
\mathrm{g}\end{array}$ & $\begin{array}{c}\text { Incidenta } \\
\text { ls Cost }\end{array}$ & $\begin{array}{c}\text { Cost } \\
\text { Price } \\
/ \mathrm{kg}\end{array}$ & $\begin{array}{c}\text { Release } \\
\text { Price/k } \\
\mathrm{g}\end{array}$ & $\begin{array}{c}\text { Subsid } \\
\mathrm{y}^{2} / \mathrm{kg}\end{array}$ & $\begin{array}{c}\text { Total } \\
\text { procureme } \\
\text { nt cost } \\
\text { (Billion) }\end{array}$ & $\begin{array}{c}\text { Expected } \\
\text { return } \\
\text { from sale } \\
\text { of stocks } \\
\text { (Billion) }\end{array}$ & $\begin{array}{c}\text { Financia } \\
\text { L Loss }^{3} \\
\text { (Billion) }\end{array}$ \\
\hline $2011-12$ & 3.19 & 1050 & 26.25 & 8.06 & 34.3 & 25 & 9.31 & 109.45 & 79.75 & 29.70 \\
$2012-13$ & 2.78 & 1200 & 30.00 & 7.98 & 37.9 & 28.1 & 9.86 & 105.58 & 78.17 & 27.42 \\
$2013-14$ & 3.68 & 1200 & 30.00 & 5.72 & 35.7 & 31.2 & 4.47 & 131.45 & 115.00 & 16.44 \\
$2014-15$ & 3.74 & 1250 & 31.25 & 6.85 & 38.1 & 32.5 & 5.6 & 142.49 & 121.55 & 20.96 \\
$2015-16$ & 3.23 & 1300 & 32.50 & 9.48 & 41.9 & 32.5 & 9.48 & 135.60 & 104.97 & 30.65 \\
$2016-17$ & 3.92 & 1300 & 32.50 & 9.51 & 42.0 & 32.5 & 9.51 & 164.68 & 127.40 & 37.36 \\
\hline
\end{tabular}

Source: Government of Punjab (2015-16)

Table 2: Bank Borrowings for Wheat Procurement (Billion Rupees)

\begin{tabular}{llllll}
\hline Year & $\begin{array}{l}\text { Old } \\
\text { Borrowing }\end{array}$ & $\begin{array}{l}\text { New } \\
\text { Borrowing }\end{array}$ & $\begin{array}{l}\text { Total } \\
\text { Borrowing }\end{array}$ & $\begin{array}{l}\text { Repayments } \\
\text { made }\end{array}$ & $\begin{array}{l}\text { Balance } \\
\text { payable }\end{array}$ \\
\hline $2011-12$ & 90.00 & 76.02 & 166.02 & 56.12 & 109.89 \\
$2012-13$ & 109.89 & 73.30 & 183.20 & 104.258 & 78.94 \\
$2013-14$ & 78.94 & 110.53 & 189.48 & 97.26 & 92.21 \\
$2014-15$ & 92.21 & 112.58 & 204.79 & 39.09 & 165.70 \\
$2015-16$ & 165.70 & 105.34 & 271.04 & 75.23 & 159.81 \\
$2016-17$ & 159.81 & 128.06 & 323.878 & 78.87 & 245.00 \\
\hline
\end{tabular}

Table 2 shows that the Punjab government borrowed 128.06 billion rupees for the purchase of wheat in 2016-17, while the old borrowings were 159.81 billion rupees. The total loan for 2016-17 amounted to Rs. Rs 323.87 billion, and the repayment made is only Rs. 78.87 billion. The amount payable in 2016-17 is Rs. 245 billion. Table 2 indicates that the total amount payable in terms of the loan is increasing since last three years from 2013-14 to 2016-17. In the period 2013-2017, loan payables increased by nearly $62 \%$. The increased minimum support price (MSP) of Rs.1300/40kg has induced farmers to produce more, but this also requires the government to purchase more quantities and get more loans.

\footnotetext{
${ }^{2}$ Subsidy per kg is calculated by adding MSP and incidental cost minus government release price

${ }^{3}$ Financial loss is calculated by multiplying the procurement quantity and subsidy per unit
} 


\section{Comparison of Minimum Support Price (MSP) and Cost of Production of Wheat in India and Pakistan}

In the following paragraphs, we compare the wheat MSPs in India and Pakistan because it has consequences for farmers' profitability and Pakistani wheat exports in the international markets.

\section{Minimum Support Price (MSP) in Pakistan and India}

Compared with regional competitors such as India, Pakistan has a higher MSP. India's wheat support price is much lower than Pakistan. The wheat MSP in India in 2016-17 is INR 650/40kg. After adjusting for the exchange rate, the MSP in Indian Punjab stands at PKR 1014/40kg PKR, while in Pakistan, MSP is PKR $1300 / 40 \mathrm{~kg}$, a difference of PKR 286. In the last five years from 2012 to 2017, the average MSP price difference between India and Pakistan was about PKR 275 / $40 \mathrm{~kg}$ (Table 3). Compared with India in 2016-17, Pakistan's wheat prices have increased by $22 \%$.

Table 3: Comparison of Minimum Support Prices (MSP) for Wheat in India and Pakistan

\begin{tabular}{llcccc}
\hline Year & $\begin{array}{l}\text { MSP/40kg in } \\
\text { Punjab, } \\
\text { Pakistan (PKR } \\
\text { Rs) }\end{array}$ & $\begin{array}{l}\text { MSP India } \\
\text { (IND rupee/40 } \\
\text { kg) }\end{array}$ & $\begin{array}{l}\text { Exchange rate } \\
\text { (INR to PKR) }\end{array}$ & $\begin{array}{l}\text { Adjusted MSP } \\
\text { of India in Pak } \\
\text { Rs. per 40 kg }\end{array}$ & $\begin{array}{l}\text { Difference between } \\
\text { Pakistan MSP \& } \\
\text { adjusted India's } \\
\text { MSP }\end{array}$ \\
\hline $2011-12$ & 1050 & 514 & 1.06 & 545 & 505 \\
$2012-13$ & 1200 & 540 & 1.67 & 902 & 298 \\
$2013-14$ & 1200 & 560 & 1.74 & 974 & 226 \\
$2014-15$ & 1250 & 580 & 1.66 & 963 & 287 \\
$2015-16$ & 1250 & 610 & 1.59 & 970 & 280 \\
$2016-17$ & 1300 & 650 & 1.56 & 1014 & 286 \\
\hline
\end{tabular}

The difference between MSP in Pakistan and the neighboring India is mainly due to lower production costs, which indicates that the Pakistani government should work to ensure that production costs are reduced through certain market mechanisms. However, if the market mechanism does not apply in the short term, subsidies should be provided to farmers during the production phase, rather than subsidies in the later stages of wheat procurement and release. At the very least, this will alleviate the government's financial burden, on the one hand reducing the processing, storage, maintenance and distribution costs of wheat, and on the other hand ensuring that the province's food prices are stable. Figure 1 compares Pakistan's production costs and MSP over the past eight years. This comparison provides a picture of the link between support prices and the profitability of Pakistani wheat farmers. Figure 1 shows that farmers' profit margins were highest in 2016-17 and lowest in 2010-11. The data shows that production costs have risen over time, so the government raised wheat support prices to maintain farmers' profit margins. In a given year, the average profit of farmers is about $25 \%$ of MSP.

This result shows that the government has failed to curb the rise in production costs, so it has been raising MSP to ensure farmers' returns. However, this practice has led to an increase in domestic prices compared to neighboring India. As a result, Pakistani wheat is not competitive on the international market. The same situation in case of losing rice competitiveness in international markets when domestic prices goes up (Javed et al., 2015). In addition, the subsidies provided during the procurement and release phases impose a heavy financial burden on government finances. Despite subsidies, wheat prices still hurt the consumer surplus because they have to pay higher wheat prices each year. 


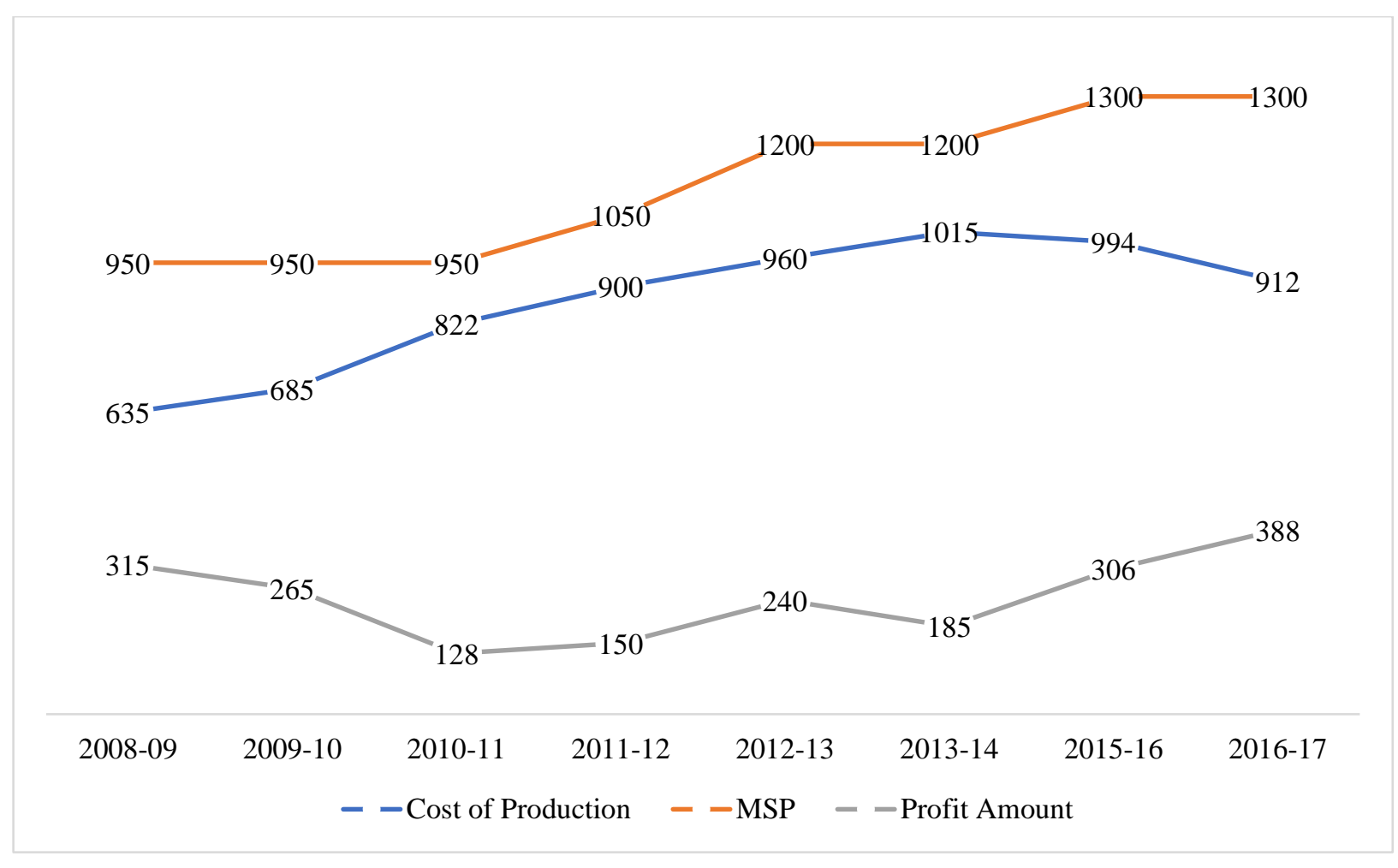

Figure 1: Cost of Production ${ }^{5} \&$ MSP Comparison

Source: Crop Reporting Services and Agricultural Marketing Information System

\section{Analysis of Cost of Production}

The trend of wheat production costs over the past 8 years is shown in Figure 2. The results show that the costs of land preparation, irrigation, fertilizer and seeds all increased over time. In the past few years, production costs have risen sharply, which has damaged farmers' profitability. Fertilizers account for the highest proportion of wheat input costs. Land preparation costs take the second place. The cost of seed and irrigation also greatly affect the cost of wheat production. Input costs can be reduced by subsidizing land preparation, seed costs, irrigation costs, and providing fertilizer to farmers at affordable prices.

A comparison of wheat production costs in India and Pakistan shows that wheat production costs are much lower in India. According to the Government of India (2015), the cost of producing $40 \mathrm{~kg}$ of wheat in 2015-16 is INR 476 (equivalent to PKR $790 / 40 \mathrm{~kg}$ ). However, the production cost of $40 \mathrm{~kg}$ of wheat in Pakistan is relatively high, at PKR 994 / $40 \mathrm{~kg}$. Due to the lower production costs of wheat, India's wheat MSP is lower than in Pakistan.
India's wheat production costs are lower due to subsidies for certified wheat and other fertilizer inputs. Statistics show that Indian farmers with less than 5 acres of land have received a $50 \%$ subsidy for certified wheat seeds. In addition, total fertilizer subsidies increased by $2.8 \%$ (from INR 709.67 billion in 201415 to INR 729.68 billion in 2015-16).

The Indian government also subsidized fertilizers at INR 12,350/ton (PKR 19487 /ton or PKR 9743/50 $\mathrm{kg}$ bags). These subsidies are paid at source i.e. to the companies. As a result, the price of urea in India is fixed at INR 268/50 $\mathrm{kg}$ bag (PKR 422 / 50kg bag). The fertilizer companies in India fix the maximum retail price (MRP) in exchange for a fixed amount of subsidy. The MRP range of DAP is 2300-2500 INR/ton (PKR 3611-3925 / ton or PKR 1805-1962 / $50 \mathrm{~kg} \mathrm{bag}$ ).

Similarly, for potash (MoP), the subsidy provided to the company is INR 9300-12350/ton (PKR 1460119390 / ton or $7300-9695 / 50 \mathrm{~kg} \mathrm{bag})^{6}$. In addition, Indian wheat growers can receive $50 \%$ certified seed subsidies from up to 5 acres of land.

\footnotetext{
${ }^{5}$ Cost of production excludes $25 \%$ investment incentive.

6 Indian Express (2016). Subsidy reform: Making direct benefit transfer work in fertilizers. Accessed at: http://indianexpress.com/article/business/budget/subsidy-reform-making-direct-benefit-transfer-work-in-fertilisers/
} 


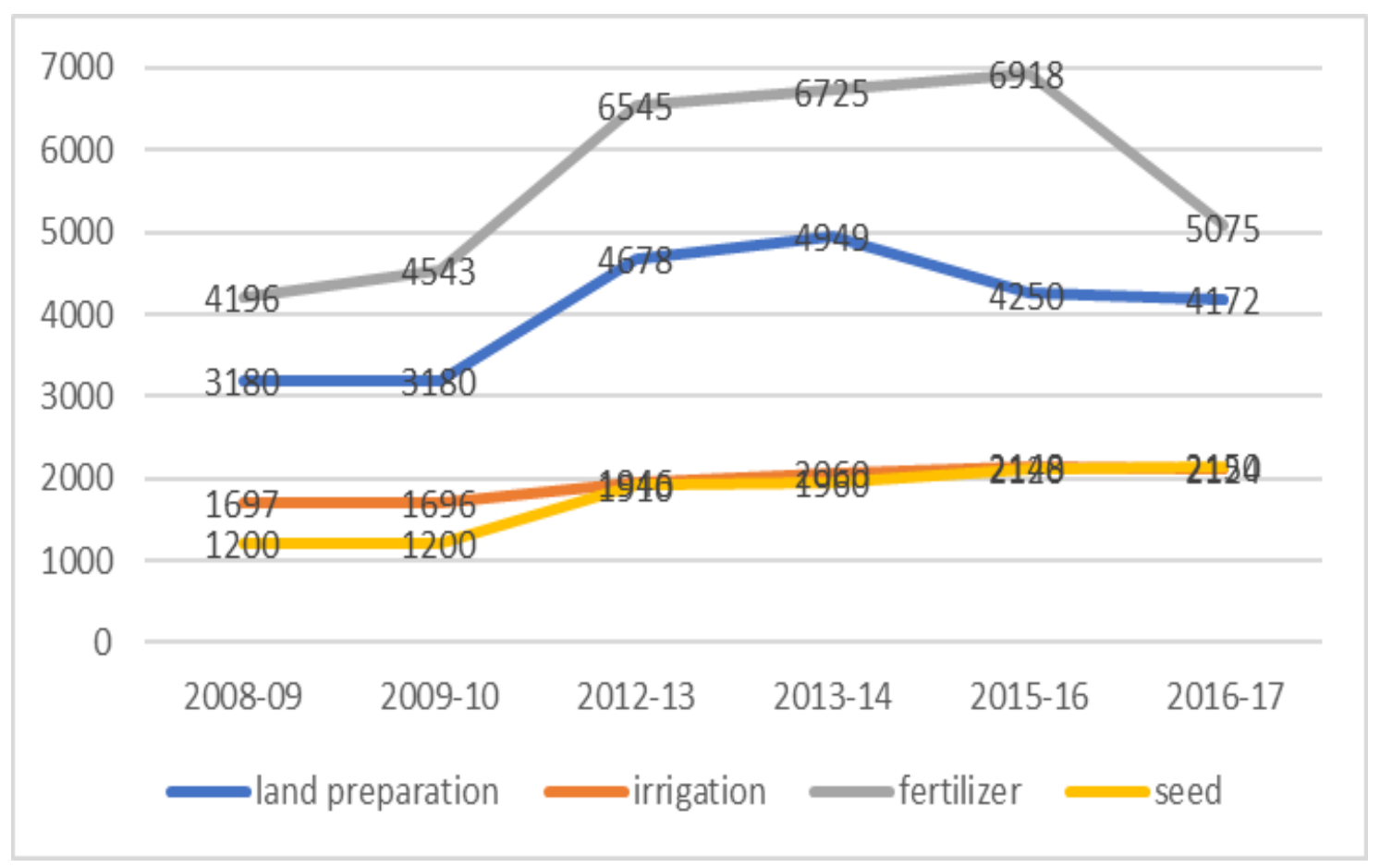

Figure 2: Cost of Production by Inputs

Source: Government of Punjab (2016)

However, in Pakistan, subsidies for inputs are lower than in India. In FY 2016-17, the total subsidy for fertilizers was 27.96 billion PKR, of which the urea subsidy was 17.16 billion PKR and the DAP subsidy was 10.8 billion PKR. This subsidy reduced the price of each $50 \mathrm{~kg}$ bagged DAP and urea fertilizer by PKR 300 and PKR 150, respectively.

Table 4: Comparison of Fertilizer Prices (NPK) Between Indian and Pakistani Punjab

\begin{tabular}{lccc}
\hline Fertilizer & $\begin{array}{c}\text { Price in Indian } \\
\text { Punjab } \\
(\text { PKR/50-Kg bag) }\end{array}$ & $\begin{array}{c}\text { Price in Pakistani Punjab } \\
(\text { PKR/50-Kg bag) }\end{array}$ & $\begin{array}{c}\text { Difference } \\
(\%)\end{array}$ \\
\hline Urea (Nitrogen) & 422 & 1760 & 431 \\
DAP (Phosphorous) & 1896 & 2800 & 142 \\
Muriate of Potash (MOP) (Potash) & 1224 & 3250 & 265 \\
\hline
\end{tabular}

Source: Government of India $(2017)^{7}$

Table 4 compares fertilizer prices in India and Pakistan. Since the price of urea and diammonium phosphate in Pakistan is much higher than in neighboring countries such as India, Bangladesh, and Sri Lanka, Pakistani farmers pay a higher price for fertilizers in the region. Pakistan can reduce input costs by reducing fertilizer prices and subsidizing farmers' inputs in the short run. Once production costs are reduced, output prices can be proportionally reduced, so farmers can diversify their production. By expanding the role of the private sector in the wheat procurement business, the economic burden of procurement can be reduced

\section{Conclusion and Policy Implications}

The minimum support price policy encourages farmers to produce more wheat. However, this policy has brought a heavy economic burden to the Punjab government. Our results indicate that the higher wheat minimum support price (MSP) has made the country lose its competitiveness in the international market. In addition, we found that the cost of wheat production in Pakistan is much higher than in India. These higher

\footnotetext{
${ }^{7}$ Accessed at http://www.fert.nic.in/page/fertilizer-policy, 2) http://agripb.gov.in/ accessed on [1-3--2017].
} 
production costs force the government to raise the MSP to maintain farmers' profitability. The high MSP is guaranteed by subsidizing the procurement and release of wheat, which imposes a heavy financial burden on government finances. In addition, the rise in wheat prices in recent years has also hurt consumers. Policymakers can redistribute subsidies by subsidizing wheat inputs, especially fertilizers and seeds, to reduce production costs. To this end, the best policy intervention may be to provide input subsidies rather than subsidies on purchase prices. A reduction in input costs will correspondingly reduce output prices, which will increase farmers' profitability, consumer surplus and the international competitiveness of Pakistani wheat.

\section{References}

Ali, M., 1990. The price response of major crops in Pakistan: An application of the simultaneous equation model. The Pakistan Development Review, 305-325.

Food and Agriculture Organization (FAO), 2013. Food and agricultural commodities production. http://faostat.fao.org/site/339/default.aspx[Onlin e] [Accessed on 12-04-15]

Government of India, 2015. Price policy for rabi crops, the marketing season 2015-16. Ministry of Agriculture, Department of Agriculture and Cooperation, Commission for agriculture cost and price. Accessed at: http://agritech.tnau.ac.in/pdf/ViewReports.pdf

Government of Punjab, 2016. Punjab development statistics 2015-16. Ministry of Agriculture, Punjab Food Department, Lahore.

Gulati, A., Sharma, P.K., Kähkönen, S., 1996. The food corporation of India: Successes and failures in Indian food grain marketing. Center for Institutional Reform and the Informal Sector, University of Maryland at College Park.

Javed, I., Ghafoor, A., Ali, A., Imran, M. A., Ashfaq, M., 2015. Margins and determinants of rice export from Pakistan to UAE market. Pakistan Journal of Agricultural Sciences, 52(2), 569-575

Khan, M.F.U., 2014. Country report-Pakistan. AsianAustralian dairy goat network, 66 .

Khan, N.Z., Ahmad, M., Rasheed, A., 2003. Wheat production in Pakistan: Saga of policy disincentives. Pakistan Development Review, 42(1), 1-27.

Krishna, R., 1963. Farm supply response in IndiaPakistan: A case study of the Punjab region. The Economic Journal, 477-487.

Niamatullah, M., Zaman, K.U., Khan, M.A., 2010. Impact of support price and fertilizer offtake on rice production and wheat acreage in NWFP, Pakistan. The Journal of Animal \& Plant Sciences, 20(1), 28-33.

Prikhodko, D., Zrilyi, O., 2013. Pakistan: Review of the wheat sector and grain storage issues country highlights. Rome: Food and Agriculture Organisation.

World Bank. 2017. Pakistan - strengthening markets for agriculture and rural transformation in Punjab program project (English). Washington, D.C: World Bank Group. Accessed at: http://documents. worldbank.org/curated/en/2448 41513566044794/Pakistan-StrengtheningMarkets-for-Agriculture-and-RuralTransformation-in-Punjab-Program-Project. 